\title{
KONTEKS DAN INFERENSI WACANA \\ PADA BAJU COUPEL MUDA-MUDI
}

\author{
oleh \\ Syahrizal Akbar \\ Universitas Prima Indonesia
}

\begin{abstract}
ABSTRAK
Dalam memahami isi atau maksud yang terkadung dalam wacana tersebut tidak cukup hanya dengan memaknai makna secara harfiah tetapi perlu memperhatikan konteks yang melingkupi wacana tersebut. Wacana yang disampaikan dalam baju muda-mudi oleh penutur tidak disampaikan secara panjang lebar atau secara lengkap dengan struktur lengkap seperti wacana pada karya tulis, buku, atau surat kabar. Metode yang digunakan dalam mengulas hasil penelitian ini adalah metode deskriptif-kualitatif. Terkait dengan prinsip penafsiran personal, yang menjadi pasrtisipan dalam wacana baju coupel muda-mudi adalah desainer baju dan konsumen. Konteks situasi yang terdapat dalam baju coupel muda-mudi mencakup tiga aspek penting yakni konteks fisik yang tidak terikat lokasi, dengan topik hubungan antarpasangan; konteks epistemis bahwa penutur dan mitra tutur dalam hal ini memiliki pengetahuan yang sama; dan konteks sosial yang menggambar relasi sosial antara penutur dan mitra tutur hanya sebatas desianer baju dan consume. Inferensi (penarikan simpulan) dalam wacana yang terdapat pada baju coupel muda-mudi yang disampaikan oleh penutur adalah kesetiaan atau kecintaan antarpasangan.
\end{abstract}

Kata kunci: Baju coupel, konteks wacana, dan inferensi wacana.

\section{Pendahuluan}

Wacana adalah satuan bahasa yang lengkap, sehingga dalam hierarki gramatikal tertinggi atau terbesar (Kridalaksana dalam Tarigan, 1987: 25). Sebagai satuan bahasa yang lengkap, maka dalam wacana itu berarti terdapat kosep, gagasan, pikiran, atau ide yang utuh, yang bisa dipahami oleh pembaca (dalam wacana tulis) dan pendengar (dalam wacana lisan). Sebagai satuan gramatikal tertinggi atau terbesar, berarti wacana itu dibentuk dari kalimatkalimat yang memenuhi persyaratan gramatikal dan persyaratan kewacanaan lainnya.

Disiplin ilmu yang mengkaji penggunaan bahasa yang nyata dalam tindak komunikasi disebut analisis wacana (Rani: 2004: 9). Analsis wacana merupakan suatu kajian yang meneliti atau menganlisis bahasa yang digunakan secara alamiah, baik dalam bentuk tulis maupun lisan (Stubbs dalam Rani, 2004: 9). Penggunaan bahasa secara alamiah tersebut 
berarti penggunaan bahasa seperti dalam komunikasi sehari-hari. Data dalam analisis wacana selalu berupa teks, baik teks lisan maupun tulis. Teks dalam hal ini mengacu pada bentuk transkripsi rangkaian kalimat atau ujaran. Kalimat digunakan dalam ragam bahasa lisan. Untuk memahami sebuah wacana, perlu diperhatikan semua hal yang terlibat dalam penggunaana bahasa tersebut.

Penelitian yang relevan pernah dilakukan sebelumnya oleh Adrian Dektisa Hagijanto. Dosen Jurusan Desain Komunikasi Visual Fakultas Seni dan Desain-Universitas Kristen Petra melakukan penelitian Retro Sebagai Wacana dalam Desain Komunikasi Visual. Penelitain tersebut mendeskripsikan bahwa dalam berbagai penampilan komunikasi tulis di Indonesia muncul beragam gaya seni/desain, gaya visualisasi, dan aplikasi kreatif visual. Aplikasi tersebut dapat terlihat pada tata letak, warna, susunan, ataupun makna pesan-pesan itu sendiri. Bentuk komunikasi yang di dalamnya bukan lagi makna-makna dari pesan, melainkan eforia permainan bebas tanda-tanda dan kode-kode yang didalamnya terdapat plesetan, humor, kritik, yang diaplikasikan pada produk-produk konsumer. Penelitain tersebut mengangkat segala bentuk retro yang terdapat di sampul kaset, iklan, dan pakaian.

Konsep penelitian Adrian tersebut memiliki relevansi dengan penelitian ini. Namun pada penelitian ini lebih menitikberatkan pada wacana yang terdapat pada baju remaja era sekarang ini yang menampilkan tampilan visual berupa simbol dan atau teks tulis.

Sumarlam, dkk. (2008: 47) mengungkapkan bahwa di samping pemahaman mengenai konteks, inferensi juga merupakan proses yang sangat penting dalam memahami wacana. Inferensi adalah proses yang harus dilakukan oleh pendengar atau pembaca untuk memahami maksud pembicara atau penulis. Pemahaman terhadap konteks, baik konteks internal maupun eksternal merupakan dasar inferensi (pengambilan keputusan). Begitu pula dalam melakukan analisis terhadap wacana yang terdapat dalam baju muda-mudi yang berpasangan atau biasa disebut coupel. Pada baju coupel muda-mudi terdapat wacana-wacana yang hendak disampaikan oleh penutur kepada mitra tutur (konsumen atau yang melihat), baik berupa teks, simbol, ataupun teks dan simbol.

Wacana yang disampaikan dalam baju muda-mudi oleh penutur tidak disampaikan secara panjang lebar atau secara lengkap dengan struktur lengkap seperti wacana pada karya tulis, buku, atau surat kabar. Tetapi, wacana yang disampaikan dalam bentuk teks-teks tidak lengkap bersifat segmental, karena hanya menyampaikan sebagaian segemen saja dari beberapa segmen yang seharusnya ada dalam teks tersebut. 
Dalam memahami isi atau maksud yang terkadung dalam wacana tersebut tidak cukup hanya dengan memaknai makna secara harfiah tetapi perlu memperhatikan konteks yang melingkupi wacana tersebut. Kesemuanya tersebut akan membantu mitra tutur (konsumen atau pembaca) dalam melakukan inferensi (penarikan simpulan) mengenai makna yang terkadung di balik wacana tersebut.

Berdasarkan asumsi-asumsi dan disokong oleh beberapa pendapat pakar tersebut, peneliti mencoba untuk mengungkap makna atau maksud yang terkandung di balik wacana yang terdapat dalam baju coupel muda-mudi dengan memerhatikan konteks internal dan konteks eksternal hingga sampai pada tahap inferensi.

\section{Kajian Teori}

Secara etimologis kata 'wacana' (discourse) berasal dari bahasa latin discurrere (mengalir ke sana kemari) dari nominalisasi kata discursus ('mengalir secara terpisah’ yang ditransfer maknanya menjadi 'terlibat dalam sesuatu', atau 'memberi informasi tentang sesuatu’) (Vass dalam Stefan Titscher, dkk., 2009:42).

Lebih lanjut beliau merinci kembali mengenai pengertian wacana sebagai berikut:

1) (secara umum); tuturan, percakapan, diskusi;

2) Penyajian diskursif sederet pemikiran dengan menggunakan serangkaian pernyataan;

3) Serangkaian pernyataan atau ujaran, sederet pernyataan;

4) Bentuk sebuah rangkaian pernyataan/ungkapan; yang dapat berupa (arkeologi): wacana ilmiah, puitis, religious;

5) Perilaku yang diatur kaidah yang menggiring ke arah lahirnya serangkaian atau sistem pernyataan-pernyataan yang saling terkait (berbagai bentuk pengetahuan) (kedokteran, psikologi, dan sebagainya) (misalnya, dalam karya Michael Fourcault);

6) Bahasa sebagai sesuatu yang dipraktikkan; bahasa tutur (misalnya, dalam karya Pul Ricoeur);

7) Bahasa sebagai suatu totalitas; seluruh bidang linguistik;

8) Mendiskusikan dan mempertanyakan kriteria validitas dengan tujuan menghasilkan consensus di antara peserta wacana (misalnya, dalam karya Jurgen Hebermas).

Berbeda dengan deskripsi kompleks Vass, Van Dijk (dalam Stefan Titscher, dkk., 2009:43) mendefinisikan wacana sebagai teks dalam konteks dan sebagai bukti yang harus diuraikan secara empiris. Hasan Alwi, dkk. (2010: 41) lebih myoroti pada aspek penyusun wacana tersebut. Beliau mengatakan bahwa wacana adalah rentetan kalimat yang berkaitan sehingga terbentuklah makna yang serasi di antara kalimat-kaliamat itu. Tidak jauh berbeda dengan pendapat Hasan Lawi, dkk., Adwimarta (dalam Budhi Setiawan, 2012: 1) menyatakan 
bahwa wacana adalah: (1) perkataan, ucapan, tutur yang merupakan satu kesatuan; (2) keseluruhan tutur.

Pernyataan yang lebih umum disampaikan oleh Henry Guntur Tarigan (dalam Budhi Setiawan, 2012: 2) yang mengatakan bahwa wacana adalah satuan bahasa yang terlengkap dan tertinggi atau terbesar di atas kalimat atau klausa dengan koherensi dan kohesi tinggi yang berkesinambungan, yang mempunyai awal dan akhir yang nyata, disampaikan secara lisan atau tertulis. Wacana bukanlah sebuah sistem yang statis. Seperti yang disampaikan oleh Michael Strange (2011: 77), discourses are not static systems, but are inherently unstable and open to change.

Berdasarkan beberapa pengertian mengenai wacana di atas, dapat disimpulkan bahwa wacana adalah tuturan atau ujaran baik dalam bentuk tulis maupun lisan yang terstruktur dan merupakan satu kesatuan yang padu.

Konteks wacana adalah aspek-aspek internal wacana dan segala sesuatu yang secara eksternal melingkupi sebuah wacana (Sumarlam, dkk. 2008: 47). Berdasarkan pengertian tersebut maka konteks wacana secara garis besar dapat dibedakan menjadi dua kelompok, yaitu konteks bahasa dan konteks luar bahasa. Konteks bahasa disebut ko-teks, sedangkan konteks luar bahasa (extra linguistic context) disebut dengan konteks situasi dan konteks budaya atau konteks saja (Malinowski dalam Sumarlam, dkk. 2008: 47).

Sumarlam, dkk. (2008: 47) menambahkan bahwa konteks bahasa atau ko-teks disebut dengan istilah "konteks internal wacana" (internal-discourse context) atau disingkat "konteks internal”; sedangkan segala sesuatu yang melingkupi wacana, baik konteks situasi maupun konteks budaya disebut "konteks eksternal wacana" (external-discourse context) atau disingkat "konteks eksternal”.

Pemahaman konteks situasi dan budaya dalam wacana dapat dilakukan dengan berbagai prinsip. Prinsip-prinsip yang dimaksud adalah sebagai berikut.

1. Prinsip Penafsiran Personal.

2. Prinsip Penafsiran Lokasional.

3. Prinsip Penafsiran Temporal.

4. Prinsip Analogi.

Inferensi adalah proses yang harus dilakukan oleh komunikan (pembaca/pendengar/ mitra tutur) untuk memahami makna yang secara harfiah tidak terdapat dalam wacana yang diungkapkan oleh komunikator (pembicara/penulis/penutur). Atau dengan kata lain, inferensi 
adalah proses memahami makna tuturan sedemikian rupa sehingga sampai pada penyimpulan maksud dari tuturan.

Inferensi terjadi bila proses yang harus dilakukan oleh pendengar atau pembaca untuk memahami makna yang secara "harfiah” tidak terdapat pada wacana yang diugkapkan oleh pembicara atau penulis (Fatimah, 1994: 43). Pembaca atau pendengar dituntut untuk mampu memahami informasi (maksud) pembicara atau penulis.

Bermacam-macam inferensi dapat diambil dari sebuah tuturan bergantung pada konteks yang menyertainya. Imam Syafi'I (dalam Sumarlam, dkk. 2008: 51) membedakan empat macam konteks pemakaian bahasa, yaitu konteks fisik, konteks epistemin, konteks linguistik, dan konteks sosial. Konteks fisik (physical context) meliputi tempat terjadinya pemakaian bahasa, objek yang disajikan dalam peristiwa komunikasi, dan tindakan para partisipan dalam peristiwa komunikasi itu. Konteks epistemis (ephistemic context) yaitu latar belakang pengetahuan yang sama-sama diketahui oleh penutur dan mitra tutur. Konteks linguistik (linguistic context) terdiri atas tuturan- tuturan yang mendahului atau yang mengikuti sebuah tuturan tertentu dalam peristiwa komunikasi. Konteks sosial (social context) yaitu relasi sosial yang melengkapi hubungan antara penutur dengan mitra tutur.

Konteks lain yang juga memiliki peranan penting dalam proses inferensi adalah konteks situasi. Konteks situasi merupakan lingkungan langsung yang berada di dalam penggunaan bahasa (Riyadi Santosa, 2010: 2). Menurut Halliday (dalam Riyadi Santosa, 2010: 2) konteks situasi terdiri dari tiga aspek: field (medan), tenor (pelibat), dan mode (sarana), yang bekerja secara simultan membentuk suatu konfigurasi kontekstual atau konfigurasi makna.

\section{Hasil dan Pembahasan}

Dalam proses pemahaman konteks, prinsip penafsiran yang digunakan hanyalah prinsip penafsiran personal karena wacana dalam baju caoupel muda-mudi hanya berkaitan dengan partisipan. Berikut sampel data yang telah dihimpun oleh peneliti.

\section{Data 1}

Bad boy go to hell (baju laki-laki)

Good girl go to heaven (baju wanita)

\section{Data 2}

Dia pacarku (baju laki-laki)

Dia pacarku (baju wanita) 


\section{Data 3}

She is my love (baju laki-laki)

He is my love (baju wanita)

\section{Data 4}

Bunda (baju laki-laki)

Ayah (baju wanita)

\section{Data 5}

Juliet just Juliet in my heart (baju laki-laki)

Romeo just Romeo in my heart (baju wanita)

\section{Prinsip Penafsiran Personal}

Telah disampaikan sebelumnya bahwa prinsip penafsiran personal berkaitan dengan siapa sesungguhnya yang menjadi partisipan di dalam suatu wacana. Dalam hal ini, siapa penutur dan siapa mitra tutur sangat menentukan makna sebuah tuturan. Terkait dengan wacana yang ada dalam baju coupel muda-mudi pada data 1 sampai data 5, yang menjadi pasrtisipannya adalah desainer baju itu sendiri dengan konsumen (pengguna/pembeli) termasuk juga semua pembaca yang “berpartisipasi” membaca wacana yang terdapat dalam baju coupel tersebut.

Dalam hal ini, penutur diduduki oleh desainer baju, dan mitra tutur dalam wacana tersebut adalah konsumen (pembaca/pembeli). Selain penentuan partisipan secara umum, dalam prinsip penafsiran personal menunjuk pada sifat-sifat para pelibat, kedudukan dan peran mereka, misalnya jenis-jenis hubungan peran apa yang terdapat di antara para pelibat.

Pada data 1 Bad boy go to hell (baju laki-laki)-Good girl go to heaven (baju wanita), jika wacana tersebut tertulis pada baju sepasang anak yang masih berusia 3-6 tahun maka pesan wacana tersebut tidak akan tersampaikan dengan baik/tepat kepada pemakai baju tersebut. Tetapi berbeda jika yang memakai baju tersebut adalah golongan muda-mudi, remaja atau dewasa, pesan yang terkandung di balik wacana tersebut tentu tersampaikan. Para pelibat dalam wacana tersebut tentunya memiliki sifat yang baik. Arti secara harfiah wacana tersebut adalah pada baju laki-laki berarti ‘laki-laki yang jahat pergi ke neraka’ dan pada baju wanita berarti 'gadis yang baik pergi ke surga'. Maksudnya bahwa penutur ingin mengajak semua mitra tutur yang membaca wacana tersebut untuk 'menuju kebaikan', sebab makna 
kedua wacana yang terdapat dalam baju coupel tersebut sama-sama mengajak untuk menjadi orang baik.

Pada data 2 baik baju laki-laki maupun baju wanita sama-sama tertulis dia pacarku. Konteks kewacanaan tersebut tentu sangat tidak cocok jika ditampilkan atau ditulis dalam baju anak-anak ataupun orang tua yang sudah melewati usia atau masa berpacaran seperti para remaja atau muda-mudi. Maksud di balik wacana dalam data 2 tersebut adalah mengungkapkan tentang kesetiaan atau pengakuan kepada umum bahwa mereka (sepasang muda-mudi pemakai baju) saling memiliki. Faktor pendukung lain yang meperkuat hal tersebut adalah dengan adanya tanda hati yang mengurung wacana tersebut dengan dibubuhi tanda panah yang menunjuk kearah pasangan masing-masing (lihat lampiran). Tidak berbeda jauh dengan apa yang diungkapkan dalam data 2, pada wacana yang terdapat dalam data 3 memiliki makna yang hampir sama. Bedanya, pada data 3 menggunakan bahasa inggris she is my love (baju laki-laki)- he is my love (baju wanita), yang berarti 'dia adalah cintaku' atau 'dia cintaku’. Selain perbedaan dalam hal bahasa, pada data 3 tidak dikurung dengan tanda hati tetapi masih hanya menggunakan simbol panah yang menunjuk pada pasangan masingmasing (lihat lampiran).

Pada data 4 terdapat wacana yang bertuliskan bunda (baju laki-laki) dan ayah (baju wanita). Kalau dicermati baju coupel tersebut sebenarnya belum layak dipakai oleh kalangan muda-mudi yang belum memiliki status suami-istri. Tetapi pada zaman sekarang ini, panggilan bunda-ayah, panggilan mama-papa di kalangan remaja sudah tidak tabu lagi. Oleh sebab itu, penutur merupakan orang yang telah membaca situasi atau perkembangan psikologis remaja dalam hal berpacaran. Wacana yang terdapat dalam baju coupel data 4 tersebut menggambar seseorang dengan sifat setia. Sebaba selain tulisan bunda atau ayah terdapat gambar hati berwarna merah yang kalau dimaknakan dan dibaca secara keseluruhan berarti ‘cinta ayah’ atau ‘cinta bunda’.

Wacana yang terdapat dalam data 5 juga mengandung makna kesetiaan. Kalangan muda-mudi sebagai sasaran produk tersebut memang layak mengenakan baju tersebut. Tulisan Juliet just Juliet in my heart (baju laki-laki) dan Romeo just Romeo in my heart (baju wanita) merupakn sebuah wacana yang terinspirasi dari kisah romantis Romeo-Juliet di Romawi. Arti secara harfiah wacana tersebut adalah 'Juliet, hanya Juliet di hatiku' dan 'Romeo, hanya Romeo di hatiku'. Jika yang mengenakan baju tersebut tidak mengetahui sama sekali tentang kisah tersebut, maka apa yang hendak di sampaikan oleh penutur tentu 
tidak tersampaikan dengan baik. Oleh sebab itu, antara penutur dan mitra tutur dalam hal ini harus sama-sama memiliki pengetahuan tentang kisah Romeo-Juliet.

\section{Konteks Situasi}

Pembahasan tentang konteks situasi dalam penelitian hanya pada tiga tataran penting yakni konteks fisik, konteks epistemis, dan konteks sosial. Beriku akan dijabarkan lebih rinci mengenai ketiga tataran tesebut.

\section{a. Konteks Fisik}

Konteks fisik ini meliputi tiga aspek, yaitu tempat terjadinya suatu peristiwa, objek atau topik yang dibicarakan, dan tindakan-tindakan para pasrtisipan dalam komunikasi. Pada sampel data yang diperoleh, dari data 1 sampai dengan data 5, tidak terikat dengan lokasi atau tempat terjadinya peristiwa. Sebab bisa saja terjadi di toko pakaian, di jalan saat melihat orang mengenakan baju tersebut, atau dimanapun ketika ada mitra tutur yang membaca waana tersebut maka telah terjadi "komunikasi” secara tidak langsung antara penutur dengan mitra tutur.

Objek atau topik yang bicarakan dalam wacana yang terdapat pada data 1 sampai dengan data 5 tersebut sebagaian besar tentang hubungan antarpasangan yang mengenakan baju coupel tersebut. Meskipun pada data 1 cenderung lebih pada himbauan untuk berprilaku baik. Tindakan-tindakan para partisipan adalah dalam hal ini lebih dititikberatkan pada mitra tutur. Mitra tutur bisa menjadi lebih setia kepada pasangan, lebih menghargai pasangan, lebih bisa memperlakukan pasangan, dan bisa saling mengerti.

\section{b. Konteks Epistemis}

Konsep epistemis berkenaan dengan masalah latar belakang pengetahuan yang sama-sama diketahui oleh penutur maupun mitra tutur. Dalam hal ini, pengetahuan penutur (desainer baju) dan mitra tutur (konsumen) bisa dikategorikan hampir sama. Hal tersebut tidak lepas dari penggunaan kata-kata yang sederhana baik dalam bahasa Indonesia maupun bahasa Inggris. Selain itu, faktor pendukung sehingga mitra tutur mampu menangkap dengan baik apa yang disampaikan oleh penutur adalah adanya penggunaan simbol-simbol yang membantu mitra tutur untuk melakukan inferensi.

\section{c. Konteks Sosial}

Konteks sosial menunjuk pada relasi sosial dan seting yang melengkapi hubungan antara penutur dan mitra tutur. Relasi sosial yang terkandung pada konteks 
wacana dari data 1 sampai dengan data 5 antara penutur dan mitra tutur adalah sebatas desainer pakaian/penjual dan konsumen.

\section{Inferensi}

Inferensi adalah proses yang harus dilakukan komunikan untuk memahami makna yang secara harfiah tidak terdapat dalam wacana (Sumarlam, 2004: 343). Untuk dapat mengambil inferensi dengan baik/tepat maka komunikan (mitra tutur) harus memahami makna konteks dengan baik karena konteks merupakan dasar bagi inferensi. Di atas telah dilakukan analisis terhadap konteks kewacanaan yang terdapat dalam baju coupel muda-mudi. Berikut adalah inferensi atas wacana-wacana yang terdapat pada lima sampel data baju coupel muda-mudi.

Telah dijelaskan secara rinci mengenai konteks kewacanaan yang terdapat dalam semua sampel data baju coupel muda-mudi, dari data 1 samapi dengan data 5. Adapun inferensi atas maksud yang terkandung pada masing-masing data tersebut adalah sebagai berikut. Pada data 1 Bad boy go to hell (baju laki-laki) dan Good girl go to heaven (baju wanita), maksud yang hendak disampaikan penutur kepada mitra tutur adalah seruan untuk menjadi seseorang yang berprilaku baik sebab bagi orang yang berkelakuan jahat akan menuju ke neraka dan bagi orang berkelakuan baik akan menuju atau ditempatkan di surga.

Wacana yang terdapat pada data 2 dan data 3 memiliki kesamaan maksud yang disampaikan oleh penutur. Perbedaannya pada bahasa yang digunakan dan simbol hati yang digunakan pada data 2, sementara pada data 3 tidak menggunakan simbol hati. Pada data 2 Dia pacarku (baju laki-laki) dan Dia pacarku (baju wanita) menunjukkan kepada semua mitra tutur lainnya (pembaca lain selain yang mengenakan baju) bahwa mereka saling memilki. Begitu juga maksud yang ingin disampaikan dalam data 3 She is my love (baju lakilaki) dan He is my love (baju wanita).

Sementara itu, pada data 4 Bunda (baju laki-laki) dan Ayah (baju wanita) dalam tampilan visual aslinya yang terpampang pada baju (lihat lampiran) sebelum kata-kata tersebut terdapat simbol hati yang berwarna merah yang berarti 'cinta ayah' atau 'cinta bunda’. Maksud yang disampaikan oleh penutur adalah yang memakai baju tersebut memiliki kecintaan kepada pasangannya, seperti layaknya suami-istri yang telah saling memiliki.

Data terakhir, yakni data 5 Juliet just Juliet in my heart (baju laki-laki) dan Romeo just Romeo in my heart (baju wanita), maksud yang disampaikan penutur kepada mitra tutur adalah tentang kesetiaan kepada pasangan masing-masing. Hal itu tampak pada wacana yang menyatakan 'hanya Juliet d hatiku’ atau 'hanya Romeo di hatiku’ dan tidak ada orang lain. 


\section{Simpulan dan Temuan}

Berdasarkan ulasan pada hasil penelitian dan pembahasan dalam penelitian ini, dapat disimpulkan beberapa hal berikut.

1. Prinsip penafsiran personal pada baju coupel muda-mudi berkaitan dengan siapa sesungguhnya yang menjadi partisipan di dalam suatu wacana, dan dalam hal ini partisipannya adalah desainer baju (penutur) dan konsumen (mitra tutur) khususnya muda-mudi.

2. Konteks situasi yang terdapat dalam baju coupel muda-mudi mencakup tiga aspek penting yakni konteks fisik yang tidak terikat lokasi, dengan topik hubungan antarpasangan; konteks epistemis bahwa penutur dan mitra tutur dalam hal ini memiliki pengetahuan yang sama; dan konteks sosial yang menggambar relasi sosial antara penutur dan mitra tutur hanya sebatas desianer baju dan konsumen.

3. Inferensi (penarikan simpulan) dalam wacana yang terdapat pada baju coupel mudamudi yang disampaikan oleh penutur adalah kesetiaan atau kecintaan antarpasangan.

4. Beberapa wacana ada yang menggunakan simbol dalam membantu mitra tutur memahami maksud dalam wacana.

5. Wacana yang terdapat dalam baju coupel muda-mudi ada yang menggunakan bahasa Indonesia dan ada yang menggunakan bahasa Inggris.

\section{Daftar Pustaka}

Andrian Dektisa Hagijanto. 2009. Retro Sebagai Wacana dalam Desain Komunikasi Visual. Surabaya: Pusat Penelitian (Research Centre) Petra Christian University.

Budhi Setiawan. 2012. Analisis Wacana. Salatiga: Widya Sari Press.

Hasan Alwi, dkk. 2010. TATA BAHASA BAKU BAHASA INDONESIA Edisi Ketiga. Jakarta: Balai Pustaka.

Riyadi Santosa. 2010. Logika Wacana: Analisis Hubungan KOnjungtif dengan Pendekatan Linguistik Sistemik Fungsional. Surakarta: LPP UNS \& UNS Press.

Siswantoro. 2005. Metode Penelitian Sastra: Analisis Psikologis. Surakarta: Muhammadiyah University Press.

Strange, Michael. 2011. "The Articulation of Transnational Campaigns: A Discourse Theoretical” Analysis Critical Approaches to Discourse Analysis across Disciplines. Vol. 5 (1): 73 - 91

Sumarlam, dkk. 2008. Teori dan Praktik Analisis Wacana. Surakarta: Pustaka Cakra. 
T. Fatimah Djajasudarma. 1994. Wacana Pemahaman dan Hubungan Antarunsur. Bandung: PT Eresco.

Titscher, Stefan, dkk. 2009. Metode Analisis Teks \& Wacana. Yogyakarta: Pustaka Pelajar. http://images.search.conduit.com/ImagePreview/?q=baju $\% 20$ couple\&ctid=CT2233703\&searchsource $=2 \&$ start $=0 \&$ pos $=31$. 